DOI: $10.4274 /$ tpa. 454

\title{
A case with theophylline intoxication
}

\author{
Ertan Sal1, Avni Kaya1, Hayrettin Temel2, Murat Başaranoğlu2, Hüseyin Çaksen2 \\ 1 Van Women's and Children's Hospital, Pediatric Clinic, Van, Turkey \\ 2 Yüzüncü Yıl University, Medical Faculty, Department of Pediatrics, Van, Turkey
}

\begin{abstract}
Summary
Theophylline is an agent used in the treatment of obstructive airway diseases. It has a risk of intoxication with serum concentrations higher than $15 \mu \mathrm{g} / \mathrm{mL}$. A seven-year-old female patient presented with complaints of vomiting and headache. She had tachycardia and other physical examination findings were found to be normal. We were informed that she ingested 10 tablets named Bronkolin ${ }^{\circledR}$ each containing 300 mg theophylline. Her serum theophylline levels were found to be $>40 \mu \mathrm{g} / \mathrm{ml}$ (normal range: $10-20 \mu \mathrm{g} / \mathrm{ml}$ ). She was monitorized and received charcoal, potassium supplementation and intravenous fluid. Her serum theophylline declined to $3.1 \mu \mathrm{g} / \mathrm{ml}$ and she was discharged. With this case presentation we wanted to emphasize that the possibility of drug intoxication should be considered in presence of hyperglycemia, hypopotassemia and tachycardia with accompanying symptoms including acute and unexplained vomiting and headache. (Turk Arch Ped 2013; 48: 55-56)
\end{abstract}

Key words: Hyperglycemia, intoxication, theophylline, vomiting

\section{Introduction}

Theophylline is a drug used in treatment of obstructive airway diseases (1) Theophylline which is a derivative of methylxantine prevents intracellular distruction of aminomonophosphate by inhibiting phosphodieaterase enzyme (1,2). Although the therapeutic level has been reported to be $10-20 \mu \mathrm{g} / \mathrm{mL}$ in some resources, there is a risk of intoxication when the blood level of theophylline is above $15 \mu \mathrm{g} / \mathrm{mL}$ (3). Therefore, when steady state is reached, the therapeutic level which is accepted to be safer and more efficient is $5-15 \mu \mathrm{g} / \mathrm{mL}$ (4). When the blood level increases above $20 \mu \mathrm{g} / \mathrm{mL}$ due to theophylline intoxication, abdominal pain, nausea and vomiting are observed, while tachycardia, arythmia and stroke may be observed above 30 $\mu \mathrm{g} / \mathrm{mL}$ (5). In addition, metabolic disorders including hyperglycemia, hypokalemia, acid-base balance disorder and leukocytosis may be noted (6). In this article, a female patient who was diagnosed as theophylline intoxication was presented to emphasize the importance of the subject.

\section{Case}

A 7-year-old female patient presented with complaints including severe vomiting and headache. Her general status was well, her consciousness was open and she appeared weak. Tachycardia was found on cardiovascular examination and other sytem examinations were found to be normal. Abnormal laboratory findings were as follows: glucose $146 \mathrm{mg} / \mathrm{dL}$, potassium $2.9 \mathrm{mEq} / \mathrm{L}$, white blood cells $25720 / \mathrm{mm}^{3}$. Complete urinalysis and blood gasas were found to be normal. On electrocardiogram, sinus tachycardia was found. Computarized tomography was found to be normal. Drug intoxication was considered because of hyperglycemia, hypokalemia and recurrent vomiting episodes and it was learned that the patient ingested 10 tablets of Bronkolin ${ }^{\circledR} 300 \mathrm{mg}$ which contains theophylline approximately 6 hours before. The blood level of theophylline was found to be $58.2 \mu \mathrm{g} / \mathrm{mL}(\mathrm{N}: 10-20 \mu \mathrm{g} / \mathrm{mL})$. The patient was monitorized and active charcoal, potassium and fluid treatment was administered. In the follow-up the vital signs were balanced, she had no complaint and the follow-up blood theophylline level was found to be $3.1 \mu \mathrm{g} / \mathrm{mL}$. The patient was discharged to come back for follow-up vizits.

\section{Discussion}

Theophylline intoxication can occur in three forms; acute, subacute and chronic (7). Negative effects especially on the cardiovascular system, nervous system, gastrointestinal system 
and metabolic system are observed (8). In acute theophylline intoxication, vomiting, tachycardia and agitation are observed classically. In addition, increase in serum glucose, calcium, creatinine kinase, myoglobin and the number of leukocytes and decrease in magnesium, potassium and phosphorus level, hypotension, arythmias, headache, shivering, nervousness, convulsion, respiratory alkalosis or metabolic acidosis may be observed $(6,9)$. Our patient who presented with complaints including vomiting and headache had hyperglycemia, hypopotassemia, leukocytosis and tachycardia.

The diagnosis of theophylline intoxication is made by measurement of blood theophylline level. Although the therapeutic level is reported to be $10-20 \mu \mathrm{g} / \mathrm{mL}$ in some resources, there is a risk of intoxication when the theophylline blood level is above $15 \mu \mathrm{g} / \mathrm{mL}$ (3). In our patient, the theophylline level was 3.5 fold higher than normal.

Administration of oral active charcoal is a good option in treatment of theophylline intoxication (10). We administered four doses of active charcoal to our patient.

Theophylline intoxication is usually observed as chronic intoxication in patients who use the drug regularly and acute intoxication is encountered rarely. Therefore, a careful history and interrogation if there is an individual who uses this drug in the family are life saving considering the significance of diagnosis and starting treatment.

In presence of hyperglycemia, hypopotassemia and tachycardia together with findings including acute and unexplained vomiting and headache, it should be kept in mind that an underlying drug intoxication may be present.

\section{References}

1. Gönlügür TE, Gönlügür U. Kanser tedavisinde teofilin. Dicle Tıp Dergisi 2007; 34: 150-154.

2. Shafer SH, Phelps SH, Williams CL. Reduced DNA synthesis and cell viability in small cell lung carcinoma by treatment with cyclic AMP phosphodiesterase inhibitors. Biochem Pharmacol 1998; 56(9): 1229-1236.

3. Demirkıran K. Yoğun bakım ünitesinde dar terapötik aralıklı ilaç kullanımı. Yoğun Bakım Dergisi 2005; 5: 240-246.

4. Self TH, Heilker GM, Alloway RR, Kelso TM, Abou-Shala N. Reassessing the therapeutic range for theophylline on laboratory report forms: the importance of 5-15 micrograms/ml.. Pharmacotherapy 1993; 13(6): 590-594.

5. Self TH, Demirkan K. Maintenance drug therapy of chronic obstructive pulmonary disease. Am J Manag Care 1999; 5(1): 91-100.

6. Eshleman SH, Shaw LM. Massive theophylline overdose with atypical metabolic abnormalities. Clin Chem 1990; 36(2): 398-399.

7. Çevik $Y$, Kavalcı C, Daş M, İzdeş S. Severe theophylline intoxication, rhabdomyolysis, disseminated intravascular coagulopathy and death: case report. Akademik Acil Tıp Olgu Sunumları Dergisi 2010; 1: 24-27.

8. Anderson W, Youl B, Mackay IR. Acute theophylline intoxication. Ann Emerg Med 1991; 20(2): 1143-1145.

9. Biberstein MP, Ziegler MG, Ward DM. Use of p-blockade and hemoperfusion for acute theophylline poisoning. West J Med 1984(4); 141: 485-490.

10. Rutten J, van den Berg B, van Gelder T, van Saase J. Severe theophylline intoxication: a delay in charcoal haemoperfusion solved by oral activated charcoal. Nephrol Dial Trasplant 2005; 20(12): 2868-2869. 